\title{
TRANSMISI ISLAM MODERAT OLEH RAJA ALI HAJI DI KESULTANAN RIAU-LINGGA PADA ABAD KE-19
}

\author{
Rina Rehayati ${ }^{1}$ dan Irzum Farihah ${ }^{2}$ \\ ${ }^{1}$ Universitas Islam Negeri Sultan Syarif Kasim Riau, Indonesia \\ ${ }^{2}$ Sekolah Tinggi Agama Islam Negeri Kudus, Indonesia \\ rina_rehayati@ymail.com
}

\begin{abstract}
In Indonesia, Islam has been recognized as a moderate Islam and is associated with archipelagic culture. Archipelagic culture constitutes a part of Islamic values. As an Islamic scholar in the Sultanate of Riau-Lingga at that time, Raja Ali Haji held a strategic position, as he was part of people in power. Once he completed an Islamic pilgrimage, as well as finished his studying Islam in Makkah and Madinah, he and his father together with Yang Dipertuan Muda (Under King) initiated to mobilize religious activities by inviting in several Islamic scholars who are the members of 'Ulamas network in Indonesia. The credibility of Indonesian Islamic scholars who spread the teachings of Islam and mobilize religious activities in the nation is acknowledged. Those people are the Islamic scholars who deeply understand Islam and understand the Shari'a of Islam comprehensively. Those Indonesian Islamic scholars, including Raja Ali Haji, certainly was able to filter out which parts of the principles of Islamic teachings that may be and may not be modified.
\end{abstract}

Keywords: Transmission, Moderate Islam, Riau-Lingga Sultanate, and Raja Ali Haji.

\begin{abstract}
Abstrak
Islam di Nusantara dikenal sebagai Islam moderat dan terkait dengan budaya Nusantara. Adapun budaya Nusantara merupakan bagian dari nilai-nilai Islam. Sebagai ulama di Kesultanan Riau-Lingga pada masa itu, Raja Ali Haji berada pada posisi strategis, karena ia bagian dari pusaran kekuasaan. Setelah selesai menunaikan ibadah haji, sekaligus belajar Islam di Makkah dan Madinah, ia dan ayahnya bersama dengan Yang Dipertuan Muda menggerakkan kegiatan keagamaan dengan mengundang beberapa ulama yang menjadi bagian dari jaringan ulama di Nusantara. Para ulama Nusantara yang menyebarkan Islam dan menggerakkan kegiatan keagamaan di Nusantara sudah diakui kredibilitasnya. Mereka para ulama yang sangat mengerti Islam dan memahami syariat Islam dengan baik. Para Ulama Nusantara tersebut, termasuk Raja Ali Haji, tentu mampu memilah bagian-bagian mana dari prinsip-prinsip ajaran Islam yang boleh dimodifikasi dan bagian-bagian mana saja yang tidak boleh dimodifikasi.
\end{abstract}

Kata Kunci: Transmisi, Islam Moderat, Kesultanan Riau-Lingga, dan Raja Ali Haji. 


\section{Pendahuluan}

Akademisi muslim Indonesia saat ini sedang ditantang oleh banyak pihak untuk menunjukkan konsep Islam moderat kepada dunia internasional, baik melalui media cetak maupun media elektronik. Padahal, jauh sebelumnya, Islam moderat telah dipraktikkan di Nusantara, termasuk di bumi Melayu, salah satunya di Kesultanan Riau-Lingga pada abad ke-19. ${ }^{1}$ Kesultanan Riau-Lingga adalah nama lain Kerajaan Melayu-Johor-Riau, setelah Sultan Mahmud Syah III lolos dari kejaran kompeni Belanda, dan bersembunyi di Lingga. Sultan merasa aman di Lingga, sehingga ia putuskan memindahkan pusat pemerintahannya yang selama ini berada di Bintan (Riau) dengan nama Kerajaan Melayu-Johor-Riau, berpindah ke Lingga, sehingga dikenal dengan nama Kesultanan Riau-Lingga. ${ }^{2}$ Terpilihnya Lingga sebagai lokasi baru kesultanan karena letak daratannya yang jauh dari pinggir Sungai Daik-

\footnotetext{
${ }^{1}$ Awalnya, Kesultanan Lingga-Riau menjadi satu dengan Kerajaan Johor-Pahang-Riau di Melaka, meliputi LinggaRiau, Kepulauan Riau, Semenanjung Melaka dan pesisir Timur Sumatera. Akibat ditandatanganinya Treaty of London (Traktat London) pada tahun 1824 oleh Belanda dan Inggris, maka wilayah kekuasaan Johor-Pahang-Riau dibagi menjadi dua. Sebagian masuk ke wilayah pendudukan Inggris di Semenanjung Melaka sampai Singapura, sedangkan sebagian lainnya, yakni Kepulauan Riau dan pesisir Timur Sumatera masuk ke wilayah pendudukan pemerintah Hindia Belanda. Lihat, Arsip Nasional, Surat-Surat Perdjandjian Antara Kesultanan Riau dengan Pemerintah V.O.C. dan Hindia Belanda 1784-1909 (Djakarta, 1970), 126; 138-140. Peninggalan sejarah tentang Kerajaan Johor-Riau, seperti benteng kota; makam Sultan Alauddin Riayat Shah II; batu nisan makam-makam kuno, masih bisa di lihat di Johor lama yang terletak di tebing kiri menghilir Sungai Johor kira-kira $27 \mathrm{~km}$ dari Bandar Kota Tinggi atau kira-kira $30 \mathrm{~km}$ dengan darat melalui jalan ke Desaru masuk ke Teluk Sengat. Lihat Kamarudin Ab. Razak, Peninggalan Sejarah di Pesisiran Sungai Johor (Selangor: Asni Sdn. Bhd., 1998), 6-17; Tenas Effendi, "Maruah Johor di Kerajaan Pelalawan", dalam Zainal Abidin Borhan (ed.), Warisan Persuratan Johor II, Perundangan dan Ketatanegaraan Melayu (Kuala Lumpur: Gillin Enterprise, 1999), 249-50; Suwardi MS, Dari Melayu ke Indonesia (Yogyakarta: Pustaka Pelajar, 2008), 23; Baca juga Barbara Watson Andaya dan Virginia Matheson, "Perceptions of the Past in South East Asia", terj. Th. Sumarthana, "Pikiran Islam dan Tradisi Melayu", dalam Dari Raja Ali Haji Hingga Hamka (Jakarta: Grafiti Pers, 1983), 99. Daud Kadir, et. al., Sejarah Kebesaran Kesultanan Lingga-Riau (Kepri: Pemerintah Kabupaten Lingga, 2008), 163.

${ }^{2}$ Pemerintah Kota Tanjung Pinang, Tanjung Pinang Land of Malay History (Tanjung Pinang: Pemko Tanjung Pinang, 2006),
} 74.
Lingga. Sungai Daik dapat dilayari sampai ke hulu, sehingga relatif terlindung dari kejaran kompeni Belanda. Selain itu, tidak mudah untuk masuk ke Sungai Daik, karena sangat bergantung dengan air pasang naik dan air pasang surut. Ketika air pasang naik, arusnya sangat deras, banyak kelokan dan sulit menentukan pinggir sungai. ${ }^{3}$ Dengan demikian, Sultan dan kesultanan berada di Lingga, sedangkan Yang Dipertuan Muda sebagai pelaksana Kesultanan Riau-Lingga tetap berada di Pulau Penyengat. Di Pulau Penyengat inilah terjadi transmisi Islam moderat pada abad ke-19.

Pola transmisi Islam moderat di Kesultanan Riau-Lingga tidak jauh berbeda dengan transmisi Islam di wilayah lain di Nusantara, yakni melalui otoritas kekuasaan raja dan kerajaan, yakni tatkala raja dan kerajaan "bersentuhan" dengan ulama dan pedagang Arab melalui perdagangan. Umat Islam Melayu di wilayah Kesultanan RiauLingga memang ada relasinya dengan ulamaulama dan para pedagang Timur Tengah yang berdagang sambil berdakwah di Asia Tenggara. Adapun transmisi Islam moderat melalui kegiatan keagamaan dan keilmuan para ulama Melayu diperoleh pada saat mereka menunaikan ibadah haji, demikian pula halnya Raja Ali Haji dan ayahnya. Raja Ali Haji dan Raja Ahmad (ayahnya) merupakan anak keturunan Bugis-Riau yang pertama kali menunaikan ibadah haji. ${ }^{4}$ Mereka tiba di Makkah pada 18 hari bulan Sya'ban tahun 1243 H/ 1827 M. Selesai menunaikan ibadah haji, mereka tinggal di Makkah selama dua tahun. Selama dua tahun itu mereka belajar Bahasa Arab (nahwu, saraf) usul al-din, fikih, dan tasawuf. Di Makkah mereka belajar ilmu-ilmu keislaman yang umumnya berkaitan dengan pemikiran Abu Hamid al-Ghazali (wafat $1111 \mathrm{M}$ ), terutama yang terkait dengan fikih dan Tasawuf. ${ }^{5}$ Kekaguman

\footnotetext{
${ }^{3}$ Ibid.

${ }^{4}$ Raja Ali Haji, Tuhfat al-Nafis, penyunting Inche Munir bin Ali (Singapura: Malaysia Printers Limited, 1932), 306.

${ }^{5}$ Saghir Abdullah, Perkembangan Ilmu Fikh dan Tokoh-Tokohnya di Asia Tenggara (Solo: Ramadani, 1985), 130. Lihat juga Hasan Junus, Raja Ali Haji: Budayawan di Gerbang Abad XX
} 
Raja Ali Haji terhadap al-Ghazali dapat dilihat pada karya-karyanya yang selalu merujuk kepada kitab Ihya ulum al-Din. ${ }^{6}$ Dengan demikian, kuat dugaan bahwa perkenalan Raja Ali Haji terhadap pemikiran dan pengaruh al-Ghazali dimulai ketika ia menunailan ibadah haji bersama ayahnya pada tahun $1243 \mathrm{H} / 1827 \mathrm{M}$.

Sepulangnya dari Makkah, ia pun mengajarkan ilmu-ilmu agama yang diperoleh di Makkah dan Madinah kepada masyarakatnya di wilayah Kesultanan Riau-Lingga, tepatnya di Pulau Penyengat yang merupakan domisili Yang Dipertuan Muda beserta keluarga besarnya. Di Makkah, mereka juga belajar dengan para ulama yang berasal dari wilayah lain, sehingga terjalin relasi yang baik antara raja dengan ulama di Indonesia. Raja Ali Haji belajar kepada Syaikh Daud bin Abdullah bin Idris al-Fattani, seorang ulama Melayu di Makkah yang sangat terpandang di kalangan murid-murid yang datang dari Melayu. ${ }^{7}$ Ia juga berguru kepada Syaikh Ismail dan Syaikh Ahmad Masyfa'. ${ }^{8}$ Selain itu, ia juga berguru kepada Haji Abdul Wahab, seorang ulama dan pernah menjabat sebagai mufti di Kesultanan Riau-Lingga. Yang Dipertuan Muda Raja Ja'far dan saudaranya juga berguru kepada Haji Abdul Wahab. ${ }^{9}$

Menurut Azyumardi Azra, terjalinnya relasi yang baik antara raja dengan ulama di Indonesia, termasuk di Kesultanan Melayu, karena adanya jaringan intelektual antara guru dengan murid di Timur Tengah dan Nusantara. Timur Tengah merupakan sumber pemikiran Islam yang kemudian mengalir ke berbagai penjuru dunia.

(Pekanbaru: UNRI Press, 2002), 83-; Juramadi Esram, Konsepsi Raja Ali Haji tentang Pemerintahan (Tanjung Pinang: CV. Milaz Grafika, 2010), 14 dan 97.

${ }^{6}$ Raja Ali Haji, Samrah al-Muhimmah, 76.

${ }^{7}$ Virginia Matheson dan M. B. Hooker, "Jawi Literature in Pattani: The Maintenance of an Islamic Tradition", Journal Malayan Branch of Royal Asiatic Society 61, no. 1 (1988): 1.

${ }^{8}$ Raja Ali Haji, Tuhfat al-Nafis, 304.

${ }^{9}$ Van der Putten dan Al Azhar, In Everlasting Friendship: Letters from Raja Ali Haji, terj. Jan van der Putten dan Al Azhar, Di dalam Berkekalan Persahabatan: Surat-surat Raja Ali Haji Kepada Von de Wall (Jakarta: Kepustakaan Populer Gramedia, 2007), 29.
Transmisi itu antara lain melalui perdagangan, pelaksanaan ibadah haji dan melalui karya-karya ulama Timur Tengah yang memuat berbagai disiplin ilmu dan pemikiran Islam. Melalui transmisi itulah kemudian terbentuk jaringan intelektual guru-murid, yang menurut Azyumardi Azra merupakan pola dominan, tidak hanya ke kawasan Melayu, tetapi juga ke berbagai penjuru dunia Islam lain. ${ }^{10}$ Melalui trasmisi itu berbagai pemikiran Islam berpengaruh terhadap tradisi lokal. Di antara tokoh agama Melayu Indonesia yang dianggap sebagai perintis pada abad ke-18 di wilayah nusantara, termasuk Malaysia dan Singapura, seperti: Al-Raniri (w.1068 H/1658 M), ${ }^{11}$ al-Sinkili (1024-1105 H/1615-1693 M), ${ }^{12}$ al-Makassari (1037-1111 H), ${ }^{13}$ Arsyad alBanjari $^{14}$ dan sebagainya. Mereka "bergerak"

\footnotetext{
${ }^{10}$ Azyumardi Azra, Jaringan Ulama Timur Tengah dan Kepulauan Nusantara Abad XVII \& XVIII, edisi revisi (Jakarta: Kencana Prenada Media Group, 2007), 51-54.

${ }^{11}$ Nuruddin al-Raniri (w. 1068 H/1658 M) ulama terkemuka di lingkungan istana Kerajaan Aceh Darussalam (1637-1644 M) pada masa pemerintahan Sultan Iskandar Sani (1637-1641 M) dan tiga tahun awal dari pemerintahan Sultan Tajul Alam Safiyah al-Din (1641-1675 M). Ia keturunan Arab Hadrami yang lahir di Raner, Gujarat, di pantai Barat India. Ia dikenal sebagai syekh dalam Tarekat Rifa'iyah, Tarekat Aydarusiyah, dan Tarekat Qadiriyah. Ia menganut mazhab Syafi'i. Berada di Makkah dan Madinah untuk menunaikan ibadah haji pada tahun 1030 H/1621 M. Tim Penulis, Ensiklopedia Tasawuf, jilid II (Bandung: Angkasa, 2008), 955-6. Ibunya orang Melayu, ayahnya berasal dari imigran Hadramaut, Arab Selatan. Tahun kelahirannya diperkirakan menjelang akhir abad ke-16. Taufiq Abdullah (ed.), Ensiklopedi Tematis Dunia Islam (Jakarta: PT Ichtiar Baru Van Hoeve, 2002), 115

${ }^{12}$ Abdur Rauf as-Sinkili (1024-1105 H/ 1615-1693 M) berasal dari daerah Fansur Barus, Sinkil di wilayah pantai Barat Laut Aceh. Selama 19 tahun belajar di Dhuha (Doha) di pesisir Teluk Persia, Yaman, Jeddah, Makkah, dan Madinah. Gurunya yang terpenting di Makkah adalah Ali bin Abdul Qadir at-Tabari (w. 1070 H/1660 M). Tim Penulis, Ensiklopedia Tasawuf, jilid I, 53-4. Taufiq Abdullah (ed.), 119.

${ }^{13}$ Muhammad Yusuf al-Makassari $(1037$ - $1111 \mathrm{H} /$ 16261699 M). Ia dikenal sebagai tokoh utama pembawa Tarekat Khalwatiyah di Nusantara, kemudian dikembangkan oleh muridnya sejak di Makkah, Abdul Bashir Tuan Rappang (w. 1723). Tarekat ini dikembangkan di Kerajaan Makasar (GoaTallo). Tim Penulis, Ensiklopedi Tasawuf, jilid III (Bandung: Angkasa, 2008), 1090-1.

${ }^{14}$ Muhammad Arsyad al-Banjari (1122 H-1227 H/ 1710-1812 M) lahir di Martapura, Kalimantan Selatan dan dikenal sebagai seorang ulama yang terkenal di Kalimantan Selatan. Usia 7 tahun belajar dengan ayahnya, kemudian setelah dewasa melanjutkan belajar ke Haramain. Di sana ia belajar bersama beberapa orang rekannya yang berasal dari Melayu-Indonesia. Guru-gurunya antara lain: As-Sammani, al-Damanhuri, Sulaiman al-Kurdi,
} 
bukan hanya melalui lisan, tetapi juga melalui tulisan. Media tulisan diperlukan, karena tidak semua wilayah dapat dikunjungi oleh para ulama, sehingga tulisan mereka dapat mewakili kehadiran ulama atau guru. Melalui karya-karya itulah para ulama masa lalu melakukan trasmisi pemikiran Islam moderat di Indonesia, termasuk di wilayah Kesultanan Riau-Lingga. ${ }^{15}$ Dengan demikian, Raja Ali Haji termasuk salah seorang ulama yang mengikuti jejak para ulama masa lalu di Nusantara, yakni ulama yang juga sekaligus penulis, dengan tujuan transmisi Islam yang moderat, kegiatan keagamaan dan keilmuan keislaman di lingkungan Kesultanan Riau-Lingga dan pulau-pulau sekitarnya.

\section{Otoritas dan Kekuasaan}

Sebelum kemerdekaan, Indonesia merupakan wilayah Nusantara yang terdiri dari kerajaankerajan. Raja sebagai pusat orientasi dan pemegang otoritas tertinggi dalam aspek politik, budaya dan agama. Setelah kemerdekaan, satu persatu kerajaan di Indonesia dihapus oleh Belanda, namun jejaknya masih dijaga dan dirawat rapi oleh keturunan raja-raja dan oleh pemerintah setempat sebagai cagar budaya, misalnya istana, masjid, makam, taman pemandian, dan lain-lain. Pada aspek keagamaan, kerajaan selalu didampingi oleh ulama, sebagi penasehat spiritual. Apalagi ulama memiliki otoritas tersendiri di masyarakat, yaitu sebagai guru dan penasihat di bidang ilmu-ilmu keagamaan. Dengan keistimewaannya tersebut, maka ulama berada di tempat tersendiri, baik di kerajaan maupun di masyarakat.

Terkait dengan otoritas kekuasaan, dapat dianalisis melalui konsep Weber tentang otoritas dan kekuasaan. Dalam teorinya, Weber mengemukakan bahwa ada tiga kategori otoritas kekuasaan, yaitu traditional authorithy,

Atallah al-Masri. Kemungkinan ia juga belajar kepada Ibrahim al-Rais az-Zamzani, sehingga ia juga dikenal sebagai ahli ilmu falaq. Lihat, Taufik Abdullah (ed.), 130.

${ }^{15}$ Azyumardi Azra, Jaringan Ulama..., 302-3. charismatic authorithy, dan legal authorithy. ${ }^{16}$ Traditional authorithy adalah otoritas berdasarkan kewibawaan yang diperoleh melalui adat-istiadat atau kebiasaan, kekudusan aturan dan kekuatan zaman dahulu, sehingga seseorang mendapatkan pengakuan memiliki kewenangan, kekuasaan atau dominasi. Weber membedakan kewenangan atau dominasi tradisional ini atas: a) gerontaksi, yakni pada tangan orang-orang tua dalam suatu kelompok; b) patriarkalisme, yaitu pada suatu satuan kekerabatan yang dipegang oleh seorang individu tertentu yang memiliki otoritas warisan; dan c) patrimonial, yaitu pegawai pemerintah yang lahir di dalam administrasi rumah tangga si pemimpin. Mereka sebagai pelayan pribadi bagi pemimpin. ${ }^{17}$ Kedua, charismatic authorithy yaitu otoritas berdasarkan kewibawaan yang diperoleh melalui kharismatik pribadi yang luar biasa, sehingga dipandang memiliki kualitas kepribadian individu yang extra-ordinary (luar biasa), bahkan diperlakukan sebagai orang yang dianugerahi kekuatan dan kualitas supernatural (adi-duniawi), superhuman (adi-insani), dan exceptional (pengecualian). Dengan demikian, ia memperoleh legitimasi dalam proses kekuasaan di tengah masyarakat. ${ }^{18}$ Ketiga, legal authorithy atau kewenangan legal-rasional, yaitu kewenangan didasarkan atas komitmen terhadap seperangkat peraturan berupa undang-undang resmi dan diatur secara impersonal. Undang-undang dan seperangkat aturan tersebut sebagai legitimasi kekuasaan di masyarakat. ${ }^{19}$

Teori tentang tiga otoritas yang dikemukakan Weber sangat relevan dengan gambaran otoritas yang terdapat di lingkungan Kesultanan RiauLingga abad ke-19. Pada masa itu, pemikiran politik Melayu masih berorientasi pada raja, sebagaimana menurut Achmad Syahid yang mengutip pendapat Chauduri, Reid, Schutte,

\footnotetext{
${ }^{16}$ Weber, "The Three Types of Legitimate Rule", translated by Hans Gerth (Berkeley: Publications in Society and Institutions, 1958), 1-11.

${ }^{17}$ Ibid., 4.

${ }^{18} \mathrm{Ibid}$.

${ }^{19}$ Ibid., 2-3
} 
Millner, yang memberi istilah "watak kekuasaan berorientasi raja". Watak kekuasaan seperti ini kemudian melahirkan budaya politik yang menempatkan raja sebagai pusat orientasi. Sehingga, tafsir Islam atas kekuasaan pada budaya politik ini cenderung bersifat legitimatif daripada oposisi. ${ }^{20}$ Tafsir model ini menurutnya terlihat pada corak beberapa karya ulama tentang politik yang pada umumnya menghasilkan konsep-konsep politik dalam Islam.

Raja Ali Haji merupakan tokoh sentral untuk Kesultanan Riau-Lingga. Ia menyandang gelar raja di depan namanya (Ali) ${ }^{21}$ karena berasal dari keturunan bangsawan di Kesultanan RiauLingga. Ia berperan sebagai penasehat Yang Dipertuan Muda, sebagai ulama, dan guru bagi masyarakatnya. Meskipun ia tidak menutup diri dengan orang yang berbeda, baik dari aspek kedudukan, suku dan agama, namun tetap teguh kepribadiannya sebagai orang Melayu. Ia pernah memprotes perilaku salah seorang raja yang menurutnya tidak sesuai dengan kepribadian Melayu. ${ }^{22}$ Ia bersahabat dekat dengan Herman von de Wall, yang selalu memotivasinya untuk menulis tentang perjalanan kehidupan di Kesultanan Riau- Lingga, terutama tentang bahasa, bahkan mereka sempat menyusun kamus bersama-sama. Sebagaimana yang diakui oleh Von de Wall dalam sejumlah publikasinya, yang menyebut Raja Ali Haji sebagai "kawan

\footnotetext{
${ }^{20}$ Achmad Syahid, "Pemikiran Politik dan Tendensi-tendensi Kuasa: Studi Pemikiran Raja Ali Haji pada Muqaddimah $f i$ Intizam dan Samarah al-Muhimmah" (Disertasi S3 yang tidak dipublikasikan, UIN Syarif Hidayatullah, 2006), 1.

${ }^{21}$ Istilah raja yang disandangkan pada Raja Ali Haji bukan menunjukkan ia sebagai seorang raja atau penguasa di kesultanan, melainkan sebagai gelar yang disandang bagi keturunan bangsawan. Pada masa itu, Penguasa Tertinggi di Kesultanan Lingga-Riau adalah Sultan yang berasal dari puak Melayu, setelah itu Yang Dipertuan Muda (YDM) yang berasal dari puak Bugis sebagai penguasa kedua setelah Sultan di Kesultanan Lingga Riau. Keturunan YDM dan Sultan diberi gelar Raja, demikian pula keturunan hasil pernikahan antara Sultan dan keluarga YDM. Dalam hal ini, Raja Ali Haji merupakan keturunan dari YDM, karena kakeknya yang bernama Raja Haji fi sabil Allah (1782-1784) adalah YDM ke-IV di Kerajaan Melayu (sebelum Treaty of London antara Belanda dengan Inggris).

${ }^{22}$ Virginia Matheson, Tuhfat al-Nafis (Kuala Lumpur: Penerbit Fajar Bakti Sdn. Bhd, 1982), 345-346.
}

baiknya". Raja Ali Haji pun menyatakan bahwa ia menganggap Von de Wall sebagai saudara yang dapat menyimpan semua rahasia kehidupan pribadinya. $^{23}$

Dari persahabatan dengan Von de Wall, Raja Ali Haji semakin matang dalam tulis-menulis. Kemampuan menulisnya sudah tidak diragukan lagi, ini dapat dilihat dari berbagai hasil karyanya yang diminati oleh banyak pihak. Melalui tulisannya pula Raja Ali Haji menggambarkan Islam yang moderat. Ia tunjukkan pada dunia bahwa ajaranajaran Islam mengajarkan penganutnya untuk berbuat baik dan tidak melakukan kerusakan di muka bumi. Semua umat Islam memiliki tanggung jawab untuk menjaga perilaku yang baik, sesuai dengan yang diperintahkan Allah dan Rasul-Nya, tidak terkecuali raja dan para pejabat kerajaan. Samrah al-Muhimmah ${ }^{24}$ merupakan karya monumentalnya yang mengajarkan bagaimana semestinya perilaku raja dan aturan pemerintahan dijalankan.

Melalui Samrah al-Muhimmah dapat dikatakan bahwa Raja Ali Haji bisa dikatakan sukses mengembangkan dan memperlihatkan Islam moderat di lingkungan Kesultanan Lingga Riau. Ia dan keluarganya pengikut setia ajaran Ahl al-Sunnah wa al-Jama'ah, suatu aliran Kalam dalam Islam yang dikenal moderat, berbeda dengan aliran Kalam Khawarij, Syi'ah, dan Mu'tazilah yang dikenal sebagai lebih "keras", dan berlawanan dengan Ahl al-Sunnah wa al-

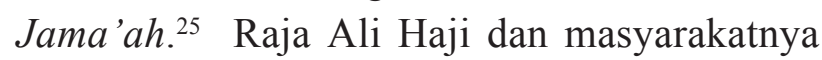
berpegang kepada Mazhab Syafi'i. ${ }^{26}$ Mazhab Syafi'i pada umumnya juga dianut oleh orang Melayu di Riau, baik Riau Daratan maupun

\footnotetext{
${ }^{23}$ Jan van der Putten dan Al Azhar, 19.

${ }^{24}$ Raja Ali Haji, Samrah al-Muhimmah. Lihat, kode Kitab dalam: T.E. Behrend, Katalog Induk Naskah-Naskah Nusantara, jilid 4 (Jakarta: Yayasan Obor Indonesia, 1998), 127. Milik Perpustakaan Nasional RI. Pada tulisan ini penulis menggunakan salinan naskah w. 18. Salinan naskah yang sama juga ada di Pulau Penyengat, Samrah al-Muhimmah Diyafah li al-Umara'i wa al-Kubara'i li ahl al-Mahkamah.

${ }^{25}$ Harun Nasution, Teologi Islam, Aliran-Aliran Sejarah Analisa Perbandingan (Jakarta: UI-Press, 1986), 61-78.

${ }^{26}$ Raja Ali Haji, Samrah al-Muhimmah, 46 dan 50.
} 
Kepulauan Riau, sebagaimana yang dikemukakan Raja Ali Haji dalam salah satu karyanya:

"Dengan ilmu naqli dan aqli dan dengan qiyas yang jali dari pada ahl al-sunnah wa al-jama'ah yaitu imam yang maha besar lagi mujtahid, yakni Maliki, Syafi'i, Hanafi dan Hanbali......beberapa jenis dari bangsa dan negara dan benua, yaitu Turki, Hindi, Arab, Syam dan Tartar, kebanyakan benua-benua tersebut memakai Mazhab Maliki, Hanafi, dan Hanbali. Adapun kebanyakan daripada pihak Jawi ini memakai Mazhab Syafi'i pada qaul yang muktamatnya dan yang 'adahnya. ${ }^{27}$

Adapun tasawuf yang dikembangkan di Kesultanan Lingga Riau adalah amalan tarekat Naqsyabandiyah. ${ }^{28}$ Tarekat ini dibawa dan dikembangkan oleh para ulama Indonesia yang belajar di Timur Tengah, kemudian dibawa ke Indonesia dan ditulis dalam bentuk naskah agar mudah dipahami oleh masyarakat. Melalui naskah ini kemudian dipelajari oleh orang-orang yang berminat mempelajari tarekat. Naskah tarekat itu kemudian menyebar ke berbagai daerah, termasuk ke Riau. ${ }^{29}$ Pada masa pemerintahan Yang Dipertuan Muda Raja Ali bin Ja'far pada tahun 1845, Raja Ali Haji diangkat sebagai penasehat spiritual dan ia pun sebagai anggota tarekat Naqsyabandiyah yang terkemuka. Ia dan adik sepupunya, Raja Abdullah menjadi anggota tarekat ini di bawah bimbingan Syekh Ismail yang datang dari Timur Tengah. ${ }^{30}$ Raja Ali Haji mengemukakan sebagai berikut:

"Syahdan, kemudian daripada itu maka Syeikh Ismail, ulama yang besar daripada ulama Jawi ini datanglah ka-Singapura.... Maka Syeikh Ismail pun datang-lah kaRiau...Maka berhimpunlah anak raja2 dan segala orang besar2 tiap2 hari bertanyakan segala hukum sah, batal, halal, haram.... Yang Dipertuan Muda pun mengambil-

\footnotetext{
${ }^{27}$ Ibid.

${ }^{28}$ Raja Ali Haji, Tuhfat, 350.

${ }^{29}$ Hasan Junus, Raja Ali Haji dan Karya-karyanya (Pekanbaru: Pusat Pengkajian Bahasa dan Kebudayaan Melayu UNRI, 1995), 100

${ }^{30}$ Raja Ali Haji, Tuhfat, 350; Lihat juga Martin van Bruinessen, Kitab Kuning Pesantren dan Tarekat Tradisi-Tradisi Islam di Indonesia (Bandung: Mizan, 1995), 335.
}

lah tarekat Naksyabandiyah serta segala anak-anak raja2 yang di Pulau Penyengat itu serta masok seluka. Maka tiap2 hari Jumaat dan Salasa tujoh, dan khatam, dan sembahyang berjemaah-lah pada tiap2 hari beramai2..." 31

Penjelasan Raja Ali Haji tersebut menggambarkan bahwa umat Islam Melayu di Riau-Lingga memang ada relasinya dengan ulama-ulama dan para pedagang Timur Tengah yang berdagang sambil berdakwah di Asia Tenggara. Selain itu, transmisi itu berpengaruh pada tradisi lokal wilayah Melayu-Riau yang sangat dipengaruhi pemikiran ulama sepulangnya mereka dari menunaikan ibadah haji dan belajar sekian lama di Makkah dan Madinah. Misalnya, Kitab Samrah al-Muhimmah karya Raja Ali Haji, isinya memperlihatkan pengaruh pemikiran para ulamaulama Arab terhadap Raja Ali Haji. Ada kesamaan konsep tentang istilah-istilah penyelenggara kerajaan, seperti: qadi, wazir, katib, dan ulama sebagai penasihat raja. Bahkan, ia sendiri menulis suatu karya yang ditulis untuk penguasa, dengan judul Muqaddimah fi al-Intizham, sebagaimana yang dilakukan oleh ulama Arab yang menulis karya untuk raja-raja mereka.

Dalam karyanya tersebut Raja Ali Haji menggambarkan tentang peran ulama-ulama Arab yang sangat signifikan di kerajaan, para ulama menjadi mufti di kerajaan pada masa itu, kemudian para ulama tersebut ada yang menulis karya sebagai nasehat bagi raja yang sedang berkuasa, serta mengenai tugas dan fungsi wazir, kadi, dan ahl al-mahkamah yang membantu tugas raja di kerajaan. Karya-karya ulama masa lalu, terutama karya dalam bentuk nasehat, ada yang murni atas inisiatif dari si pengarang sendiri dengan tujuan memberi nasehat kepada raja, dan ada juga karya yang merupakan pesanan bagi para raja. ${ }^{32}$

\footnotetext{
${ }^{31}$ Raja Ali Haji, Tuhfat, 350.

${ }^{32}$ Karya-karya ulama berupa nasehat untuk penguasa yang bermazhab Syafi'i misalnya Al-Mawardi (974-1058 M), penulis Kitab Al-Ahkām al-Sultaniyyah. Nizam al-Mulk (1018-1092), penulis Kitab Siyar al-Mulk. Al-Ghazali (1058-1111 M), penulis Kitab Al-Tibr al-Masbuq fi Nasihah al-Muluk.
} 
Dari karya-karyanya tersebut menggambarkan bahwa Raja Ali Haji lahir dan dibesarkan di lingkungan keluarga bangsawan yang religius. Pada masa itu, Yang Dipertuan Muda juga seorang yang religius. Sebagaimana yang dikemukakan oleh Raja Ali Haji bahwa Yang Dipertuan Muda VIII Raja Ali bin Ja'far (1845-1857) adalah seorang yang sangat peduli terhadap kegiatan pendidikan dan keagamaan. Yang Dipertuan Muda Raja Ali bin Ja'far juga mengundang para ulama ke Pulau Penyengat, seperti: Habib Syaikh Syakaf, Syed Hasan al-Hadad, Syaikh Ahmad Jibrati, Syaikh Muhammad Arsyad al-Banjari, Tuan Kyai Beranjang, Tuan Haji Shihabuddin, Haji Abu Bakar Bugis. ${ }^{33}$ Ia pun mengembangkan dan mengamalkan tarekat Naqsyabandiyah. ${ }^{34}$ Raja Ali bin Ja'far tercatat sebagai raja yang mempunyai kepedulian terhadap perkembangan Islam di Pulau Penyengat. Ia mengeluarkan anggaran belanja yang besar untuk pendidikan Islam di Pulau Penyengat. ${ }^{35}$ Kepemimpinan model Raja Ali bin Ja'far yang peduli dengan kegiatan keagamaan di lingkungan keluarga raja-raja Pulau Penyengat dan di masyarakat berlanjut pada masa Yang Dipertuan Muda IX, Raja Abdullah (1857-1858). ${ }^{36}$ Dengan demikian, dapat dikatakan bahwa hampir seluruh Yang Dipertuan Muda (penguasa kedua setelah Sultan di Kesultanan Lingga-Riau) berpengaruh dan berperan penting di Kesultanan Melayu, mulai dari masa berjayanya Kerajaan Melayu Johor-Riau, sampai dengan masa Kesultanan RiauLingga. Islam berada dalam lingkaran kekuasaan kesultanan, sehingga pemikiran politik Melayu yang berorientasi pada raja berpengaruh terhadap penafsiran atas ajaran Islam di ranah Melayu.

\section{Islam Melayu yang Akomodatif pada Jejak Karya Raja Ali Haji}

Jejak Islam Melayu masa lalu yang dipengaruhi oleh kerajaan masih dapat disaksikan

\footnotetext{
$\overline{{ }^{33} \text { Raja Ali Haji, Tuhfat al-Nafis, } 340 .}$

${ }^{34}$ Ibid., 350.

${ }^{35} \mathrm{Ibid}$.

${ }^{36}$ Ibid., 364.
}

sampai saat ini. Terutama pada ritual "lingkaran Hidup" (kelahiran, pernikahan, dan kematian), dan pernak-pernik budaya Melayu masih dipertunjukkan. Untuk konteks Indonesia, perkembangan budaya Melayu dikenal berada di wilayah Riau daratan dan Kepulauan Riau, Sumatera, Kalimantan, Sulawesi, dan lain-lain. Perbedaannya, Melayu di wilayah Sumatera, Kalimantan, Sulawesi terdiri dari beragam agama, suku, dan ras, sedangkan Orang Melayu di Riau dikenal sebagai muslim Melayu. Menurut Parsudi Suparlan, Orang Melayu di Riau membedakan diri mereka dengan Orang Melayu di wilayah lain dan suku-suku lainnya berdasarkan pada ciriciri sebagai berikut: Beragama Islam; berbahasa Melayu; Beradat-istiadat Melayu, baik berkenaan dengan upacara "lingkaran hidup" (kelahiran, pernikahan, dan kematian), maupun dalam pengaturan kehidupan keluarga dan masyarakat. Adapun ciri-ciri kepribadian orang Melayu menurut Parsudi Suparlan, yaitu: taat menjalankan shalat lima waktu, khususnya shalat Jum'at; ramahtamah; mementingkan hidup kekeluargaan; secara ekonomi tidak agresif (qana'ah). ${ }^{37}$

Berdasarkan kriteria tersebut, maka perbedaan kemampuan dan pandangan dunia para ulama Melayu dalam memahami doktrin-doktrin normatif di dalam al-Qur'an, serta lingkungan sosio-historis dan kultural setempat telah memunculkan "wajah Islam” Melayu yang khas dan berbeda dengan "wajah Islam" di belahan dunia lain, termasuk pada "Islam Jawa" yang diidentifikasi oleh Geertz sebagai Islam Abangan, Santri, dan Priyayi. ${ }^{38}$ Bassam Tibi

\footnotetext{
${ }^{37}$ Parsudi Suparlan, Orang Sakai di Riau: Masyarakat Terasing dalam Masyarakat Indonesia (Jakarta: Yayasan Obor Indonesia, 1995), 50-51.

${ }^{38}$ Pembagian tiga "wajah Islam" di Jawa berdasarkan hasil penelitian Clifford Gerrtz dalam bukunya The Religion of Java (London: The Free Press of Glencoe, 1960). Hasil penelitian Geertz merupakan salah satu teori dari tujuh teori yang dianggap berpengaruh dalam penelitian agama dan kultur di dunia. Tujuh orang peneliti yang dimaksud: 1) E.B. Tylor dan James Frazer; (2) Sigmund Freud; (3) Emile Durkheim; (4) Karl Marx; (5) Mircea Eliade; (6) E. Evans-Pritchard; (7) Clifford Geertz. Lihat, Daniel L. Pals, Seven Theories of Religion, terj. Ali Noer Zaman, Seven Theories of Religion (Yogyakarta: Qalam, 2001), 17.
} 
menyebut dengan istilah cultural accommodation of change. ${ }^{39}$ Hemat penulis, meskipun Islam Melayu tidak sama “wajah"nya dengan Islam di wilayah lain, namun realitasnya, muslim Melayu memang memiliki kekhasan tersendiri, Islam yang sesuai dengan kultur Melayu yang relatif akomodatif. Kultur Melayu yang akomodatif sangat bersesuaian dengan Islam moderat. Muslim Melayu bukanlah muslim yang fanatik, sehingga tidak pernah terdengar terjadinya pertentangan ideologis dan konflik rasis yang signifikan di willayah Riau. Untuk mengatakan bahwa Islam yang ditampilkan oleh ulama Melayu Riau masa lalu adalah Islam moderat dapat disaksikan melalui ekspresi keislaman mereka. Islam disentuh dan disampaikan melalui seni dan budaya. Raja Ali Haji menyampaikan konsep-konsep Islam melalui karya seni sastra berupa pantun, pepatah, dan gurindam. Dakwah melalui pendekatan seni dan budaya setempat ternyata efektif, karena bahasa dakwah yang dihiasi dengan bahasa sastra, seperti pantun, gurindam, pepatah, sangat akrab di telinga masyarakat Melayu, sehingga konsep Islam secara perlahan disosialisasikan, dipahami, dan diekspresikan melalui seni sastra.

Syed Nasir bin Ismail dan Abdul Samad bin Ahmad mengemukakan bahwa orang Melayu gemar bersyair. Bentuk puisi Melayu berupa pantun untuk menyuarakan dan melukiskan hati si penulis, awalnya sederhana, lama kelamaan sesuai dengan zamannya berkembang menjadi lebih kompleks. Syair-syair itu ada jenis roman, sejarah, agama, sindiran atau kiasan, dongeng dan sebagainya. ${ }^{40}$ Ini menggambarkan bahwa karakteristik Islam Melayu bersifat akomodatif dan moderat. Dengan perspektif ini, Islam Melayu Riau terlihat lebih fleksibel dan bermartabat. Sebagaimana bisa dicermati pada ungkapan Raja

\footnotetext{
${ }^{39}$ Bassam Tibi, Islam and The Cultural Accommodation of Social Change (Oxford: Westview Press, 1990), 7.

${ }^{40}$ Syed Nasir bin Ismail dan Abdul Samad bin Ahmad, Bahasa dan Kesusasteraan Melayu dari Segi Kebudayaan (Kuala Lumpur: Dewan Bahasa dan Pustaka, 1957), 14-15.
}

Ali Haji dalam Gurindam Duabelas sebagai berikut:

"Ini gurindam pasal kelima

Jika hendak mengenal orang berbangsa, lihat kepada budi dan bahasa.

Jika hendak mengenal orang yang berbahagia, sangat memeliharakan yang sia-sia.

Jika hendak mengenal orang mulia, lihatlah kepada kelakuan dia.

Jika hendak mengenal orang yang berilmu, bertanya dan belajar tiadalah jemu.

Jika hendak mengenal orang yang berakal, di dalam dunia mengambil bekal.

Jika hendak mengenal orang yang baik perangai, lihat pada ketika bercampur dengan orang ramai". ${ }^{41}$

Kandungan makna sosial-budaya dalam isi Gurindam Duabelas pasal kelima di atas menunjukkan bahwa muslim Melayu mempunyai karakter budayanya sendiri yang khas dan unik, tidak memiliki kesamaan "sense" akan warisan budaya dan sejarah dengan muslim lain di dalam wilayah negara Indonesia atau di luar negara Indonesia, budaya itulah yang kemudian berpengaruh terhadap pemikiran politik dan Islam-nya orang Melayu.

Menurut Azyumardi Azra, Islam di Asia Tenggara sering dipandang oleh banyak orientalis sebagai Islam periferal, karena jauh dari "bentuk asli" yang terdapat dan berkembang di pusatnya di Timur Tengah. Islam Melayu telah bercampur dengan berbagai kebudayaan yang melingkupinya sehingga seolah-olah Islam hanya bagian dari kebudayaan tersebut. Meskipun demikian, Islam Melayu berhasil memperlihatkan konsep Islam yang damai dan rahmah li al-'alamin. Azra melihat dari beberapa penelitian di Asia Tenggara yang menurutnya masih ditemukannya suatu ciri yang distingtif Islam di Melayu dengan Islam di Timur Tengah. Misalnya, pencampuradukkan antara ajaran Islam dengan praktik perdukunan ${ }^{42}$ atau dengan

\footnotetext{
${ }^{41}$ Raja Ali Haji, Gurindam Dua Belas (Pekanbaru: UNRI Press, 2003), 5 .

${ }^{42}$ Azyumardi Azra, "Kebangkitan Islam akan muncul dari Melayu", dalam Moflich Hasbullah (ed.), Asia Tenggara,
} 
ritual "lingkaran hidup" seperti: ritual kelahiran, pernikahan dan kematian..$^{43}$ Dari fenomena yang ada di masyarakat, Islam di wilayah Melayu memang telah diinterpretasikan sesuai dengan budaya dan nalar orang Melayu. Sebagaimana definisi kebudayaan menurut Geertz, kebudayaan adalah pola makna-makna yang diwariskan secara historis yang terwujud dalam simbolsimbol yang dengannya manusia berkomunikasi, melestarikan dan mengembangkan pengetahuan mereka tentang kehidupan dan sikap-sikap terhadap kehidupan. ${ }^{44}$ Senada dengan Geertz, Woodward mendefinisikan kebudayaan sebagai suatu sistem pengetahuan sadar dan di luar sadar di dalam pikiran individu, sehingga kemudian disebut aksioma pengetahuan budaya. ${ }^{45}$ Demikian pula Menurut Claude Levi Strauss, kultur adalah refleksi dari struktur biologis universal dari pikiran manusia. ${ }^{46}$ Heidy Shri Ahimsa-Putra mendefinisikan kebudayaan sebagai produk atau hasil kerja dari aktivitas nalar manusia (human mind). Dalam hal ini, Heidy mensejajarkan dengan bahasa yang juga merupakan produk dari aktivitas nalar manusia. ${ }^{47}$ Dengan demikian, kebudayaan merupakan refleksi nalar manusia tentang kehidupan dalam bentuk perilaku yang sama dan berulang-ulang sesuai dengan

Konsentrasi Baru Kebangkitan Islam (Bandung: Fokus Media, 2003), 115.

${ }^{43}$ Pencampuran ajaran Islam dengan perdukunan atau hal-hal yang mistis tidak hanya terjadi di wilayah Melayu, tetapi banyak juga terjadi di belahan dunia lain, termasuk dunia Arab sebagai tempat kelahiran Islam. Namun, kekhas-an Islam Melayu di Riau begitu kental, terutama tatkala menyaksikan ritual acara "lingkaran hidup" (kelahiran, pernikahan, kematian) dan ritual pada acara-acara tertentu, misalnya tradisi tepuk tepung tawar pada pembuka acara ritual, mendoa, syukuran, balimau kasai dan sebagainya. Tim peneliti Kebudayaan dan Kemasyarakatan Universitas Riau, Budaya Tradisional Melayu Riau (Pekanbaru: Dinas Kebudayaan, Kesenian dan Pariwisata, 2005), 92-3.

${ }^{44}$ Clifford Geertz, The Interpretation of Cultures, terj. Kebudayaan dan Agama (Yogyakarta: Kanisius, tt), 4-10.

${ }^{45}$ Woodward, terj. Islam Jawa: Kesalehan Normatif versus Kebatinan (Yogyakarta: LkiS,1999), 69.

${ }^{46}$ Edith Kurzweil, The Age of Structuralism, Levi-Strauss to Foucault, terj. Nurhadi, Jaring Kuasa Strukturalisme Strukturalisme: Dari Claude Levi-Strauss sampai Foucault (Yogyakarta: Kreasi Wacana, 2004), 29.

${ }^{47}$ Heidy Shri Ahimsa-Putra, Strukturalisme Levy Staruss: Mitos dan Karya Sastra (Yogyakarta: Bentang Budaya, 2001), 23-25. pemahaman dan konteks lingkungan, alam, pola pikir, dan cara memaknai suatu simbol oleh sekelompok manusia. Produk aktivitas nalar tersebut dikomunikasikan dengan bahasa, sehingga bahasa dan kebudayaan berkembang beriringan dalam kehidupan manusia. Demikian pula pada bahasa dan kebudayaan Melayu, juga menjalani proses yang sama dalam memaknai simbol-simbol keagamaan dan budaya di kelompok masyarakatnya.

\section{Raja Ali Haji Pengembang Bahasa Melayu}

Raja Ali Haji dikenal sebagai tokoh bahasa Melayu yang berjasa mengembangkan bahasa Melayu di Indonesia, sehingga Bahasa Melayu menjadi lingua-franca. Berkenaan dengan ini, menurut James T. Collins, bahasa Melayu merupakan turunan Austronesia Purba, dimulai sebagai satu dari beberapa varian bahasa yang saling berhubungan erat dan digunakan di Kalimantan Barat kurang lebih dua juta tahun yang lalu. Dengan berkembangnya teknologi perairan sekitar tahun $100 \mathrm{M}$., penutur bahasa Melayu Purba berpindah tempat ke arah Barat menyeberangi laut Cina Selatan melalui pulau Tambela dan Riau ke Sumatera, kemudian ke ujung Selatan Benua Asia yang dikenal dengan Semenanjung Malaysia. Perpindahan juga sampai ke sebelah Barat Daya Pulau Luzon (Teluk Manila), lalu ke Maluku, kemudian ke Selatan menyeberangi Selat Karimata ke Bangka Belitung, Sungai Musi dan Pantai Barat Jawa, termasuk Jakarta sekarang. ${ }^{48}$ Penelitian James T. Collins ini menunjukkan bahwa Kalimantan merupakan asal-muasal bahasa Melayu berikut kebudayaan Melayu itu sendiri.

Setelah Kerajaan Melayu Johor-PahangRiau dipisahkan oleh Belanda dan Inggris, maka bahasa Melayu yang dikembangkan juga terpisah menjadi dua bagian. Bahasa Melayu yang dikembangkan oleh Abdullah bin Abdul

\footnotetext{
${ }^{48}$ James T. Collins, Malay World Language: a short history, terj. Alma Evita Almanar, Bahasa Melayu, Bahasa Dunia, cet. 2 (Jakarta: Pustaka Obor Indonesia, 2011), 4-5.
} 
Kadir di Kerajaan Melayu Pahang, Johor, Trengganu, dan Singapura. Abdullah bin Abdul Kadir kemudian mendapat gelar "munsyi" yang berarti guru bahasa berkembang menjadi bahasa Melayu di Singapura, Malaysia dan Brunei Darussalam. ${ }^{49}$ Sedangkan bahasa Melayu di Lingga-Riau dikembangkan oleh Raja Ali Haji dan cendekiawan yang tergabung dalam Rusydiyah Club. Bahasa Melayu Lingga-Riau dikembangkan oleh Raja Ali Haji melalui kitab tata bahasa Melayu yang ia beri judul Bustan alKatibin, ditulis sekitar tahun 1857. Setelah itu ia menulis kamus yang berjudul Kitab Pengetahuan Bahasa. ${ }^{50}$ Dengan demikian, bahasa Melayu semakin berkembang dan selanjutnya menjadi lingua-franca, karena digunakan sebagai bahasa resmi negara Indonesia. ${ }^{51}$

Bahasa Melayu menjadi lingua-franca sejak abad ke-7 oleh masyarakat di kawasan Nusantara, terutama dalam dunia perdagangan. Pada saat itu, bahasa Melayu tidak hanya dipakai oleh orang Melayu, melainkan oleh kelompok-kelompok etnis lainnya, sehingga bahasa Melayu berpotensi menjadi bahasa nasional, dan tentunya diperkaya oleh sumbangan bahasa lain. ${ }^{52}$ Bahasa Melayu pada masa itu telah berkembang dengan pesat sebagai bahasa perantara dan bahasa diplomat di kalangan suku-suku bangsa di Nusantara, dan

\footnotetext{
${ }^{49}$ Kedua tokoh ahli bahasa Melayu yang mewakili wilayah kekuasaan Inggris dan Belanda, yaitu Abdullah bin Abdul Kadir Munsyi dan Raja Ali Haji mempunyai latar belakang kehidupan yang berbeda. Abdullah bin Abdul Kadir Munsyi diasuh, dibesarkan, dan bergaul dengan kebudayaan Barat, terutama Inggris. Sedangkan Raja Ali Haji dididik dan dibesarkan dalam lingkungan masyarakat Melayu yang kuat berpegang kepada ajaran agama Islam. Keduanya memperlihatkan corak tulisan yang berbeda. Abdullah bin Abdul Kadir Munsyi lebih banyak menonjolkan kebaikan-kebaikan Inggris, sedangkan Raja Ali Haji lebih banyak menonjolkan peranan masyarakat Melayu yang diwarnai dengan budaya lain. Lihat, Pemerintah Kota Tanjung Pinang, 108

${ }^{50}$ UU. Hamidy, Riau sebagai Pusat Bahasa dan Kebudayaan Melayu (Pekanbaru: P2BKM UNRI, 1983), 148.

${ }^{51}$ Azaly Djohan, "Sekapur Sirih Ketua LAMR", Suwardi MS. dan Zulkarnain (ed.), Bahasa Melayu Sebagai Lingua Franca (Yogyakarta: Pustaka Pelajar, 2010), 7.

${ }^{52}$ Tim Penyusun, Ensiklopedi Nasional Indonesia, Jilid 14, cet. 4 (Jakarta: PT. Deta Pamungkas, 2004), 232.
}

sebagai bahasa perdagangan. ${ }^{53}$

Selain sebagai bahasa resmi kerajaan, bahasa Melayu juga berperan penting sebagai pemersatu orang Melayu yang beragam suku dan ras, di samping juga sebagai bahasa dagang internasional di Selat Malaka atau Asia Tenggara. Bahasa Melayu juga diperkaya dengan tradisi dan budaya Islam, karena Melaka merupakan pusat penyebaran agama Islam. Oleh sebab itu, masuknya perbendaharaan tradisi dan budaya Islam ke dalam kosa-kata bahasa Melayu membuka peluang bagi bahasa Melayu menjadi bahasa ilmu pengetahuan dan bahasa seni. ${ }^{54}$ Dengan demikian, bahasa Melayu selain memiliki ciri identitas dan kepribadian yang khas, juga menempati kedudukan yang khas terhadap orang Melayu. ${ }^{55}$ Wajar bila kemudian para pendiri bangsa Indonesia memilih bahasa Melayu sebagai bahasa nasional dan bahasa pemersatu bangsa Indonesia.

\section{Genealogi Islam Moderat di Kesultanan Riau- Lingga}

Lingkungan keluarga Raja Ali Haji dikenal teguh berpegang kepada al-Qur'an dan Hadis, dan menganut aliran Ahl al-Sunnah wa alJama'ah. ${ }^{56}$ Term Ahl al-Sunnah wa al-Jama'ah

\footnotetext{
${ }^{53}$ Bernard H.M. Vlekke, Nusantara (Nederland: W. Van Hoeve Ltd., 1965), 81

${ }^{54}$ James T. Collins, 20-7; Lihat juga, U.U. Hamidy, "Nilai Strategis Bahasa Melayu sebagai Bahasa Pergaulan Serantau", Suwardi MS. dan Zulkarnain (ed.), 143-6. Pengaruh Islam yang masuk ke dalam bahasa dan sastra Melayu nampak jelas pada abad ke-19 dengan munculnya para penulis muslim seperti: Raja Ali Haji, Abdullah bin Abdul Kadir Munsyi, Said Mahmud, Haji Muhammad Said, dan lain-lain. Dari tulisan-tulisan mereka yang bercorak Islam, tersebar pulalah ajaran-ajaran Islam ke Masyarakat secara meluas. Lihat Pemerintah Kota Tanjung Pinang, 108.

${ }^{55}$ Perkembangan dan penyebaran bahasa Melayu dimulai pada masa kerajaan Melayu Melaka dan Johor dan pembinaan dan pembakuannya pada masa Raja Ali Haji sehingga dikenal sebagai bahasa Melayu Tinggi. Maksudnya, pembakuan yang dilakukan oleh Raja Ali Haji untuk membedakan bahasa Melayu tulisan dengan bahasa Melayu dialek percakapan sehari-hari. Usaha pembakuan bahasa Melayu Raja Ali Haji dilanjutkan oleh Van Ophuiysen dengan rencana ejaan bahasa Melayu dengan huruf Arab dan Latin. Lihat, M. Diah Zainuddin, "Tingkat Keterimaan Bahasa Melayu di Serantau", Suwardi MS. dan Zulkarnain (ed.), 115.

${ }^{56}$ Raja Ali Haji, Samrah al-Muhimmah, 11.
} 
atau yang lebih dikenal dengan nama kelompok Sunni, diambil dari golongan mayoritas yang moderat dan berpegang teguh kepada Sunnah, serta menerima Hadis-Hadis Sahih, sebagai lawan dari golongan Muktazilah, suatu golongan minoritas yang dianggap tidak berpegang teguh pada sunnah dan meragukan orisinalitas Hadis yang mengandung sunnah atau tradisi. ${ }^{57}$ Aliran Ahl al-Sunnah wa al-Jama'ah merujuk kepada pemikiran Abu Hasan al-Asy'ari. ${ }^{58}$ Dengan demikian, pemikiran keislaman Raja Ali Haji jelas diwarnai oleh landasan teologis Sunni yang berpegang kepada Ahl al-Sunnah wa al-Jama'ah dalam pelaksanaan iman, Islam, dan ihsan (akidah, syariah, dan akhlak). Sejarah mencatat bahwa Islam Sunni mulai berkembang pada masa Dinasti Saljuk, sebuah dinasti para sultan berhaluan Sunni yang memerintah daerah-daerah kekuasaan Islam mendampingi Khalifah Abbasyiah yang Sunni. ${ }^{59}$ Pada masa ini terjadi satu pola politikkeagamaan, yaitu sistem peradilan Islam diatur oleh para ulama yang berperan sebagai hakim (kadi), sedangkan kekuatan militer menjadi basis keteraturan sosial dan diatur oleh otoritas politik

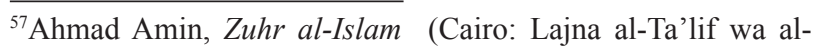
Tarjama wa al-Nashr, 1946), 96.

${ }^{58} \mathrm{Abu}$ Hasan al-Asy'ari lahir di Basrah tahun $260 \mathrm{H} / 873 \mathrm{M}$, wafat tahun $324 \mathrm{H} / 935 \mathrm{H}$. Pada awalnya ia murid al-Jubba'i, salah seorang terkemuka pada aliran Muktazilah. Tetapi, kemudian ia keluar dari aliran ini karena berbeda prinsip teologis dengan gurunya yang beraliran Muktazilah. Ibid., 65 .

${ }^{59}$ Nama Saljuk pada Dinasti Saljuk dinisbahkan kepada Saljuk bin Tuqaq (busur baru), salah seorang turunan Turki, yang bertempat tinggal di Transoxasania. Dia seorang yang cerdas, memiliki wawasan yang luas, dan tokoh suku Ghuz. Jika dirunut, nenek moyang mereka sama dengan nenek moyang Turki Usmani. Lihat, Mundzirin Yusuf, "Bani Saljuk dan Kebangkitan Peradaban Daulah Abbasiyah", Jurnal Thaqafiyyat, Jurnal Kajian Budaya Islam 14, no. 1 (2013): 9. Dinasti Saljuk berhasil mengalahkan Dinasti Samaniyah dan Dinasti Buwaihi pada tahun $429 \mathrm{H} / 1036 \mathrm{M}$ di bawah pimpinan Tughril Bek (10371063). Tughril Bek digantikan oleh keponakannya bernama Alp Arselan (1063-1072 M). Alp Arselan wafat tahun 1072 M, ia digantikan oleh anaknya bernama Malik Syah, tapi karena usianya baru 18 tahun, maka pemerintahan dipercayakan kepada Nizam al-Mulk, seorang wazir yang kuat dan cakap, dan berhasil membawa kejayaan Dinasti Saljuk, baik dari perekonomian, maupun pendidikan. Lihat K. Ali, A Study of Islamic History (Jakarta: PT RajaGrafindo Persada, 1997), 270-73; Lihat juga, Antony Black, The History (Edinburgh: Edinburgh University Press, 2011), 91-96.
}

yang sah. ${ }^{60}$ Sunni mengembangkan diri sebagai mitra utama penguasa politik-militer, sehingga terjalin relasi antara Sultan dan para ulama yang saling bekerjasama dalam kepemimpinan dan saling bergantung satu sama lain. ${ }^{61}$ Fenomena ini gambaran kesuksesan era Dinasti Saljuk dalam memperkuat posisi Ahl al-Sunnah, karena paham Sunni bukan hanya memiliki otoritas sosial, tetapi juga terintegrasi dalam kehidupan politik.

Dalam perjalanan sejarahnya, perkembangan intelektual Sunni sebagian berasal dari Timur, yaitu Khurasan, suatu daerah di Asia Barat yang tidak jatuh ke tangan Syiah. ${ }^{62}$ Asy'ariy dan pengikutnya menolak spekulasi rasional Muktazilah. Mereka membawa ajaran pewahyuan murni yang merupakan bagian penting dalam pemikiran hukum Syafi'i ke dalam teologi, yakni menyangkal kemampuan akal manusia dalam menerjemahkan wahyu menjadi bahasa atau postulat buatan manusia selain yang telah tersusun dalam teks-teks suci. ${ }^{63}$ Pengaruh paham Asy'ariyah terhadap kehidupan intelektual secara umum cukup signifikan. Para pengikutnya mendukung pandangan bahwa semua peristiwa disebabkan langsung oleh kehendak Allah. Koherensi intelektual tidak dibutuhkan di sini, sebagaimana terungkap dalam frase kuncinya: "Jangan bertanya bagaimana" (bi la kaifa). Doktrin-doktrin semacam itu dikembangkan pertama kali di Nisapur, sebuah pusat aktivitas intelektual di bagian Timur Iran, dan kemudian meraih dukungan yang cukup luas dari kalangan Sunni. Paham Asy'ariah menyingkirkan paham Muktazilah serta seluruh kecenderungan diskursus rasional dalam teologi. ${ }^{64}$ Kesuksesan paham teologis Asy'ariah dalam memikat banyak pengikut diakui tidak bisa dilepaskan dari keberadaan al-Asy'ariy yang berafiliasi dengan

\footnotetext{
${ }^{60}$ Antony Black, 82-83.

${ }^{61}$ Ibid.

${ }^{62} \mathrm{Ibid}$.

${ }^{63}$ Ibid., 83.

${ }^{64}$ Majid Fakhri, A History of Islamic Philosophy, terj. R. Mulyadi Kartanegara, Sejarah Filsafat Islam (Jakarta: Pustaka Jaya, 1987), 294.
} 
Mazhab Syafi'i. ${ }^{65}$

Larangan durhaka kepada raja yang dikemukakan oleh Raja Ali Haji dalam Samrah al-Muhimmah, juga ada kesamaan dengan ajaran al-Asy'ariy yang melarang melawan Imam, sebagaimana pandangan Nizam al-Mulk ${ }^{66}$ dan al-Ghazali, pengikut setia ajaran Asy'ariah dan bermazhab Syafi'i. Al-Asy'ariy mencela orang-orang membenarkan tindakan melawan Imam, dan ia menolak pemberontakan bersenjata menentang Khalifah yang sedang berkuasa dan menolak perang saudara. ${ }^{67}$ Demikian pula dengan Nizam al-Mulk (1018-1092 M) seorang ahli fikih bermazhab Syafi'i di Nisapur, dan sebagai Wazir Dinasti Saljuk, pada masa kekuasaan Alp Arselan (1055-1073 M) berpendapat bahwa penguasa adalah pemilik utama atas seluruh tanah, negara, dan rakyat adalah milik Sultan.$^{68}$ Nizam berperan penting dalam proses pembentukan struktur peradilan, perpajakan, dan administratif di wilayah kekuasaan Dinasti Saljuk. Ia juga membangun Madrasah Nizamiyah di Bagdad pada tahun 1065-1067 M, dengan tujuan agar rakyat bisa menikmati pendidikan gratis. Selain itu, melalui Madrasah Nizamiyah dia para ulama dan staf kesekretariatan dapat memicu kebangkitan politik, budaya, dan intelektual Sunni. Ia sendiri yang menunjuk tenaga pengajar di Madrasah Nizamiyah, termasuk al-Ghazali ia yang memanggilnya agar mengajar di Madrasah Nizamiyah. ${ }^{69}$

Sikap politik Sunni, yakni politik tanpa perlawanan (non-resistensi) menjadi sikap yang secara luas diikuti oleh kalangan Sunni. Sikap ini juga diperlihatkan oleh Ibn Qudamah Muwaffaq

\footnotetext{
${ }^{65}$ Ahmad Mahmud Subhi, Fi Ilmi al-Kalam: Dirasah Falsafiyyah li Ara'i al-Firaq al-Islamiyyah fi Usul al-Din al-Asy'ariyah),

jilid II (Beirut: Dar al-Nahdah al-'Arabiyyah, 1985), 33.

${ }^{6}$ Nizam al-Mulk lahir di dekat Tunisia pada tahun 1018 dan wafat pada tahun 1092. Ia ditunjuk menjadi wazir pada oleh Alp Arselan (1055), dan diserahi tanggung jawab atas daerah Khurasan (1059-1063), akhirnya menjadi perdana menteri. Antony Black, 91.

${ }^{67}$ Ibid., 107.

${ }^{68}$ Ibid., 92.

${ }^{69}$ Ibid., 107.
}

al-Din (1146-1223), yang menyatakan bahwa pemberontakan politik hanya akan mengacaukan persatuan umat Islam. Oleh sebab itu, tidak sepatutnya menentang seorang pemimpin, kecuali ia memerintah untuk mengingkari Tuhan. ${ }^{70}$ Selain sikap politik non-resistensi, karakteristik Sunni lainnya adalah anti rasionalisme, yaitu kecenderungan mengambil jalan tengah di antara Aliran Khawarij, Murji'ah, dan Syi'ah, serta antara Jabariah dan Qadariah, tujuannya juga untuk menjaga kemaslahatan dan kesatuan umat Islam. ${ }^{71}$ Dengan karakteristik semacam itu, Sunni secara religio-politik seringkali dimasukkan ke dalam tipologi kelompok tradisionalis. Tradisionalis Sunni ditunjukkan melalui; (1) sikap perlawanannya terhadap rasionalisme Muktazilah, (2) penerimaan mereka terhadap sufisme, dan (3) ketundukan mereka kepada penguasa. $^{72}$

Pandangan Ahl al-Sunnah mengenai kekhalifahan dikembangkan juga oleh seorang pengikut al-Syafi'i, yaitu Abu al-Hasan Ali alMawardi (974 M- 1058 M), yang menjadi hakim di Nisapur dan kemudian menjadi qadi al-quda (ketua hakim) di Bagdad pada masa Saljuk awal. Ia seorang ahli hukum reformis yang terobsesi mengadaptasikan syariat dengan keadaan masyarakat. Ia ingin menjelaskan hubungan antara Khalifah, Sultan, dan Amir dalam kerangka syariat, sehingga memasukkan hubungan ini ke dalam sistem agama. ${ }^{73}$ Atas perintah alQa'im juga, ia menulis karya utamanya tentang politik yang merupakan genre fikih, Kitab alAhkam al-Sultaniyyah (Peraturan-Peraturan Kekuasaan) yang ditulis antara 1045 M-1058 M. Ia mengatakan bahwa ia ingin memahami pandangan para fuqaha dan prinsip-prinsip yang

\footnotetext{
${ }^{70}$ Ibid., 82.

${ }^{71}$ Pemeliharaan kesatuan umat dilakukan terutama ketika terjadi perbedaan pendapat, melalui konsensus atau ijmak sebagai solusi dalam menengahi perbedaan pendapat, dan kemudian menjadi salah satu sumber hukum. Lihat, Fazlur Rahman, Islamic Methodology in History (Pakistan: Islamic Research Institute, 1964), 85.

${ }^{72}$ Ibid., 88-91.

${ }^{73}$ Antony Black, The History, hlm. 86.
} 
menetapkan hak-haknya, agar ia bisa menjalankan dengan tepat; dan mengetahui kewajibannya, serta dapat melaksanakan dengan sempurna. Semua itu bertujuan untuk menunjukkan keadilan dalam pelaksanaan dan penilaian hukum, serta didorong oleh keinginan untuk menghargai hakhak setiap orang dalam hubungan yang saling menguntungkan. ${ }^{74}$

Dengan demikian, kuat dugaan bahwa pengembangan Islam moderat yang dikonstruk dan dikembangkan Raja Ali Haji di Kesultanan Riau-Lingga dipengaruhi oleh pemikiran dan peran tokoh-tokoh Sunni terdahulu. Pengaruh Sunni sangat jelas tergambar pada buku-buku rujukan yang ia gunakan dalam pengembaraan intelektualitasnya, ${ }^{75}$ seperti: Mir'at al-Tullab, karya al-Sinkili, al-Risalah karya Muhammad bin Idris al-Syafi'i. Ihya Ulum al-Din karya alGhazali (w. 1111). ${ }^{76}$ Adapun di bidang bahasa Arab, seperti: al-Awamil, karya Abu Abdullah Muhammad ibn Dawud al-Sinhaji (1273/4-1323 M), al-Jurumiyah, karya Abu Ali Muhammad bin Yusuf bin Usman al-Hasani al-Sanusi (w. 1486) karya Umm al-Barahin, Jawhar al-Tauhid, karya Syaikh Ibrahim al-Laqaniy. ${ }^{77}$ Syarh Bidayah alHidayah, karya al-Ghazali (w. 1111 H) Minhaj al-'Abidin ila Gannat Rabb al-Alamin, karya al-Ghazali (w. 1111 H), Alfyyah Ibn Malik, karya Jamaluddin Muhammad ibn Abdullah ibn Malik (600 H-672 H/1230 M-1274 M), Fath al-Wahhab bi Syarh Manhaj al-Tullab, karya Zakariya al-Ansari. ${ }^{78}$ Dengan demikian, selain belajar 'Ulum al-Qur'an dan 'Ulum al-Hadis, ia juga mempelajari kitab-kitab bahasa, merupakan rujukan dalam bahasa Arab dan mempelajari Islam dan proses pembentukan karakter seorang muslim.

Selain mempelajari kitab-kitab, proses pembelajaran keislaman juga dilakukan melalui pengalaman tarekat Naqsyabandiyah. Raja,

\footnotetext{
${ }^{74} \mathrm{Ibid}$.

${ }^{75}$ Raja Ali Haji, Tuhfat al-Nafis, 335-336.

${ }^{76}$ Raja Ali Haji, Samrah al-Muhimmah, 64.

${ }^{77}$ Ibid., 25

${ }^{78}$ Ibid., 27.
}

anak-anak raja, dan masyarakat setempat secara bersama-sama mempelajari ilmu tasawuf. Setiap malam Jum'at dan Selasa mereka membaca Khatam Tawajjuh, yaitu salah satu bacaan zikir dalam Tarekat Naqsyabandiyyah, selain itu, mereka juga mengerjakan salat wajib berjamaah setiap hari. ${ }^{79}$ Pada masa Yang Dipertuan Muda VIII, Raja Ali bin Ja'far ( 1845-1857), ditegakkan hukum tegas bagi perampok, pejudi, dan perbuatan pelanggaran moral lainnya. ${ }^{80}$ Pembangunan masjid disempurnakan, dan dilengkapi dengan asrama musafir, penginapan bagi guru-guru agama yang datang dari berbagai daerah, serta ruang muzakarah sebagai tempat diskusi keagamaan. ${ }^{81}$ Paparan ini menggambarkan lingkungan Raja Ali Haji yang dikelilingi suasana religius, masjid dibangun bukan hanya sebagai tempat ibadah, tetapi juga sebagai tempat belajar bagi rajaraja, pembesar istana, dan para ulama di Pulau Penyengat. Suasana ini dibangun sebagaimana kehidupan ulama-ulama Sunni terdahulu yang mengintegrasikan penguasa dengan ulama, seperti yang dirintis oleh Nizam al-Mulk dan al-Ghazali, meskipun wujud penyelenggaraan pendidikan di Pulau Penyengat dalam bentuk relatif sederhana dibandingkan dengan Madrasah Nizamiyah yang dibangun oleh Nizam al-Mulk pada masa Dinasti Saljuk, namun berdampak luas terhadap Riau dan sekitarnya. Pembudayaan tradisi keagamaan di Pulau Penyengat terus berlanjut, meskipun Kesultanan Lingga-Riau dihapus oleh Belanda pada tahun $1911 .^{82}$

\section{Kesimpulan}

Transmisi keislaman di Kesultanan RiauLingga dilakukan melalui pendidikan dan kegiatan keagamaan (tarekat) merupakan contoh konkret bahwa Islam yang diajarkan dan disampaikan oleh para ulama di nusantara

\footnotetext{
$\overline{{ }^{79} \text { Raja Ali Haji, Tuhfat al-Nafis, }} 350$.

${ }^{80}$ Ibid., 347.

${ }^{81}$ Ibid. Masjid ini memiliki empat menara yang tinggi dan empat kubah yang terlihat dari kejauhan dan masih berdiri kokoh sampai saat ini.

${ }^{82}$ Pemerintah Kota Tanjung Pinang, 92.
} 
pada masa lalu adalah Islam yang moderat, untuk memperlihatkan bahwa Islam moderat sebagai Islam yang rahmah li al-alamin. Para ulama "bergerak" melalui lisan dan tulisan, artinya selain berdakwah secara lisan, mereka juga produktif menulis. Melalui karya-karya itulah para ulama masa lalu melakukan trasmisi pemikiran Islam moderat. Karya-karya mereka masih dipelajari sampai saat ini. Raja Ali Haji termasuk salah seorang ulama yang mengikuti jejak para ulama nusantara, yakni sebagai ulama sekaligus penulis. Ia mendialogkan pemikiran keislamannya dengan media tradisi Orang Melayu pada masa itu, yaitu dengan tulisan aksara Arab Melayu. Tulisannya dilengkapi dengan untaian syair-syair dan gurindam. Melalui syair-syair dan gurindam tersebut ia berhasil menyampaikan nilai-nilai Islam universal di wilayah Kesultanan Riau-Lingga dan Semenanjung Melaka. Bahkan, hingga saat ini Gurindam Dua Belas tetap dipelajari dan menjadi salah salah satu karya fenomenal untuk lintas generasi

Keberhasilan transmisi Islam moderat melalui pendekatan budaya lokal diakui oleh banyak pihak, karena masyarakat mudah memahami ajaran Islam. Islam moderat dimaknai sebagai Islam yang integral dengan konsep pemikiran dan ekspresi budaya masyarakat lokal, dalam konteks ini, masyarakat Melayu di Kesultan Riau-Lingga dan Semenanjung Melaka. Gerakan pembaruan Raja Ali Haji dalam transmisi pemikiran Islam di Kesultanan Riau-Lingga di Pulau Penyengat dan pulau-pulau di sekitarnya dilakukan dengan cara mendatangkan beberapa ulama yang diakui kredibilitasnya. Mereka para ulama yang sangat mengerti Islam dan memahami syariat Islam dengan baik. Para ulama nusantara tersebut, termasuk Raja Ali Haji, tentu mampu memilah bagian-bagian mana dari prinsip-prinsip ajaran agama yang boleh diubah dan hal-hal mana saja yang tidak boleh dimodifikasi.

Dengan demikian, Raja Ali Haji berhasil memperkuat (reinforcement) jatidiri Melayu dan mengintegrasikan budaya Melayu dengan
Islam, sebagaimana yang telah dirintis para ulama nusantara terdahulu yang menurutnya berhasil membangun fondasi Islam di Semenanjung Melaka. Mereka berhasil melakukan perubahan sosial perspektif kesejarahan dengan tidak mengabaikan tradisi Melayu yang bercorak Islam Sunni dan bermazhab Syafi'i. Tegasnya, bahwa pembudayaan tradisi Melayu yang integral dengan Islam tersebut tidak boleh hilang atau diubah, karena tradisi tersebut sudah ada terlebih dahulu dan merupakan endapan psikologis Orang Melayu di Riau-Lingga, sehingga menjadi identitas bagi orang Melayu di Riau (Saat ini, Riau daratan dan Kepulauan Riau).

\section{Daftar Kepustakaan}

Achmad Syahid. "Pemikiran Politik dan Tendensitendensi Kuasa: Studi Pemikiran Raja Ali Haji pada Muqaddimah fi Intizam dan Samarah al-Muhimmah". Disertasi S3 yang tidak dipublikasikan. UIN Syarif Hidayatullah, 2006.

Ali, K. A Study of Islamic History. Jakarta: PT RajaGrafindo Persada, 1997.

Amin, Ahmad. Zuhr al-Islam. Cairo: Lajna alTa'lif wa al-Tarjama wa al-Nashr, 1946.

Andaya, Barbara Watson dan Matheson, Virginia. "Perceptions of the Past in South East Asia". Terj. Th. Sumarthana, "Pikiran Islam dan Tradisi Melayu”. Dalam Dari Raja Ali Haji Hingga Hamka. Jakarta: Grafiti Pers, 1983.

Arsip Nasional Republik Indonesia. Surat-surat Perdjandjian Antara Kesultanan Riau dengan Pemerintah V.O.C. dan Hindia Belanda 1784-1909. Djakarta: ARNAS, 1970.

Azaly Djohan. "Sekapur Sirih Ketua LAMR". Dalam Suwardi MS. dan Zulkarnain (ed.), Bahasa Melayu sebagai Lingua Franca. 
Yogyakarta: Pustaka Pelajar, 2010.

Azyumardi Azra. Jaringan Ulama Timur Tengah dan Kepulauan Nusantara Abad XVII \& XVIII. Edisi revisi. Jakarta: Kencana Prenada Media Group, 2007.

-------. "Kebangkitan Islam” di Asia Tenggara?, Pengantar dalam Renaisans Islam Asia Tenggara. Bandung: PT Remaja Rosdakarya, 1999.

Black, Antony. The History of Islamic Political Thought: From the Prophets to the Present. Second Edition. Edinburgh: Edinburgh University Press, 2011.

Bruinessen, Martin van. Kitab Kuning Pesantren dan Tarekat Tradisi-tradisi Islam di Indonesia. Bandung: Mizan, 1995.

Collins, James T. Malay World Language: a Short History. Terj. Alma Evita Almanar. Bahasa Melayu, Bahasa Dunia. Cetakan Kedua. Jakarta: Pustaka Obor Indonesia, 2011.

Daniel L. Pals. Seven Theories of Religion. Terj. Ali Noer Zaman. Seven Theories of Religion. Yogyakarta: Qalam, 2001.

Daud Kadir, et. al. Sejarah Kebesaran Kesultanan Lingga-Riau. Kepri: Pemerintah Kabupaten Lingga, 2008.

Fakhri, Majid. A History of Islamic Philosophy. Terj. R. Mulyadi Kartanegara. Sejarah Filsafat Islam. Jakarta: Pustaka Jaya, 1987.

Gerrtz, Clifford. The Religion of Java. London: The Free Press of Glencoe, 1960.

-------. The Interpretation of Cultures. Terj. Kebudayaan dan Agama. Yogyakarta: Kanisius, t.th.

al-Ghazali, Abu Hamid Muhammad bin Muhammad al-Thusi. Ihya Ulum al-Din. Jilid I. Beirut: Dar al-Qutaibah, 2003.

Hasan Junus. Raja Ali Haji: Budayawan di
Gerbang Abad XX. Pekanbaru: UNRI Press, 2002.

. "Riau dan Dunia Naskah Melayu Lama". Dalam Heddy Shri Ahimsa-Putra (ed.). Masyarakat Melayu dan Budaya Melayu dalam Perubahan. Yogyakarta: Adicita Karya Nusa, 2007.

dkk. Muqaddima fi Intizam al-Wazaif al-Mulk Khususan Ila Maulana wa Sahibina Yang Dipertuan Muda Raja Ali al-Mudabbir li al-Biladi al-Riauwiyah wa Sairi Dairatihi. Tercap di Ofis Gubernemen Lingga- Rajab, 1304.

, dkk. Raja Ali Haji dan Karya-Karyanya. Pekanbaru: Pusat Pengajian Bahasa dan Kebudayaan Melayu, UNRI, 1995.

-------. Engku Puteri Raja Hamidah, Pemegang Regalia Kerajaan Riau. Pekanbaru: Unri Press, 2002.

Heidy Shri Ahimsa-Putra. Strukturalisme Levy Staruss: Mitos dan Karya Sastra. Yogyakarta: Bentang Budaya, 2001.

Juramadi Esram. Konsepsi Raja Ali Haji tentang Pemerintahan. Tanjung Pinang: CV. Milaz Grafika, 2010.

Kuntowijoyo. Identitas Politik Umat Islam. Bandung: Mizan, 1989.

Kurzweil, Edith. The Age of Structuralism, LeviStrauss to Foucault. Terj. Nurhadi. Jaring Kuasa Strukturalisme Strukturalisme: Dari Claude Levi-Strauss, Sampai Foucault. Yogyakarta: Kreasi Wacana, 2004.

Matheson, Virginia Hooker. "Concept of State in the Tuhfat al-Nafis ( The Pricious Gift)". dalam Anthony Reid dan Lance Castles. Pre-Colonial State System in the Southeast Asia. Kuala Lumpur: Rajiv Priters, 1979.

-------. Tuhfat al-Nafis Karangan Raja Ali Haji. Kuala Lumpur: Yayasan Karyawan dan 
Dewan Bahasa dan Pustaka, 1998.

-------. Tuhfat al-Nafis: Sejarah Melayu Islam. Terj. Ahmad Fauzi Basri. Kuala Lumpur:

Dewan Bahasa dan Pustaka Kementerian Pendidikan Malaysia, 1991.

Mundzirin Yusuf. "Bani Saljuk dan Kebangkitan

Peradaban Daulah Abbasiyah". Jurnal Thaqafiyyat, Jurnal Kajian Budaya Islam 14, no. 1 (2013).

Parsudi Suparlan. Orang Sakai di Riau Masyarakat Terasing dalam Masyarakat Indonesia. Jakarta: Yayasan Obor Indonesia, 1995.

Pemerintah Kota Tanjung Pinang. Tanjung Pinang: Land of Malay History. Tanjung Pinang: Pemerintah Kota Tanjung Pinang, 2006.

Rahman, Fazlur. Islamic Methodology in History. Pakistan: Islamic Research Institute, 1964.

Raja Ali Haji. Samrah al-Muhimmah. 1275 $\mathrm{H} / 1858 \mathrm{M}$.

-------. Silsilah Melayu dan Bugis dan Sekalian Raja-rajanya. Singapura: Matba'ah alImam, $1392 \mathrm{H}$.

------. Kitab Pengetahuan Bahasa. Singapura: Matba'ah al-Ahmadiah, 1927.

------. Tuhfat al-Nafis. Disunting oleh Inche Munir bin Ali. Singapura: Malaysia Printers Limited, 1932.

-------. Gurindam Dua Belas. Pekanbaru: UNRI Press, 2003.

Saghir Abdullah. Perkembangan Ilmu Fikh dan Tokoh-Tokohnya di Asia Tenggara. Solo: Ramadani, 1985.

Subhi, Ahmad Mahmud. Fi Ilmi al-Kalām: Dirāsah Falsafiyyah Li Arā'i al-Firāq al-Islamiyyah fì Ushul al-Dīn (alAsy'ariyah). Jilid II. Beirut: Dar al-
Nahdah al-'Arabiyyah, 1985.

Suwardi MS. Dari Melayu ke Indonesia. Yogyakarta: Pustaka Pelajar, 2008.

Syed Nasir bin Ismail dan Abdul Samad bin Ahmad. Bahasa dan Kesusasteraan Melayu dari Segi Kebudayaan. Kuala Lumpur: Dewan Bahasa dan Pustaka, 1957.

Taufiq Abdullah (ed.). Ensiklopedi Tematis Dunia Islam. Jakarta: PT Ichtiar Baru Van Hoeve, 2002.

Tenas Effendi. "Maruah Johor di Kerajaan Pelalawan”. Dalam Zainal Abidin Borhan (ed.). Warisan Persuratan Johor II, Perundangan dan Ketatanegaraan Melayu. Kuala Lumpur: Gillin Enterprise, 1999.

Tibi, Bassam. Islam and The Cultural Accommodation of Sicial Change. Oxford: Westview Press, 1990.

Tim Peneliti Kebudayaan dan Kemasyarakatan Universitas Riau. Budaya Tradisional Melayu Riau. Pekanbaru: Dinas Kebudayaan, Kesenian dan Pariwisata, 2005 .

Tim Penulis. Ensiklopedia Tasawuf. Jilid II. Bandung: Angkasa, 2008.

Tim Penyusun. Ensiklopedi Nasional Indonesia. Edisi Kedua. Cetakan Ketiga. Jakarta: Balai Pustaka, 1994.

UU. Hamidy. Riau sebagai Pusat Bahasa dan Kebudayaan Melayu. Pekanbaru: P2BKM UNRI, 1983.

Vlekke, Bernard H.M. Nusantara. Nederland: W. Van Hoeve Ltd., 1965.

Woodward, Mark. Islam Jawa: Kesalehan Normatif versus Kebatinan. Yogyakarta: LkiS, 1999. 